\title{
T1 PELVIC ANGLE IN IMPROVEMENT OF PAIN IN HIGH-GRADE LUMBAR SPONDYLOLISTHESIS
}

\author{
ÂNGULO T1 PÉLVICO NA MELHORA DA DOR NA ESPONDILOLISTESE LOMBAR \\ DE ALTO GRAU
}

\section{ÁNGULO T1 PÉLVICO EN LA MEJORA DEL DOLOR EN LA ESPONDILOLISTESIS LUMBAR DE ALTO GRADO}

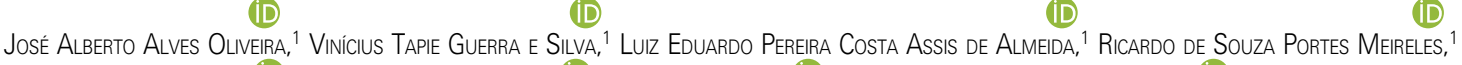 \\ Gullherme de Rezende Lopes, ${ }^{1}$ Alexandre Pexoto de Mello, ${ }^{1}$ Paulo Cesar Almeida, ${ }^{2}$ Luis Eduardo Carell teixera da Silva ${ }^{1}$ \\ 1. Instituto Nacional De Traumatologia e Ortopedia Jamil Haddad, Spine Surgery Service, Rio de Janeiro, RJ, Brazil. \\ 2. Universidade Estadual do Ceará, Center for Health Sciences, Fortaleza, CE, Brazil.
}

\begin{abstract}
Objective: To evaluate the correlation between global sagittal alignment variables and pain improvement after surgery for High-Grade Spondylolisthesis (HGS). Methods: A sample with 20 patients with L5-S1 HGS, submitted to arthrodesis with instrumentation from 01/2004 to 12/2016. Patients' demographic data, types of surgeries, complications, sagittal alignment parameters, and Visual Analog Scale (VAS) score (ranging from 0 to 4) were recorded before surgery and at the last follow-up. The data were processed in SPSS 22.0. The confidence level was 0.05. Results: The majority of the sample were women, 17 (85\%); age at surgery: $52.60 \pm 17.15$ years; mean follow-up: $3.58 \pm 1.62$ years; isthmic etiology, 16 (80\%) and dysplastic, 4 (20\%); Meyerding Grading 3: 12 (60\%), Grading 4: 3 (15\%) and Grading 5: 5 (25\%); SDSG type 4: 6 (30\%), type 5a: 3 (15\%), 5b: 3 (15\%), type 6: 7 (35\%) and not classified 1 (5\%); surgery: in situ fusion 3 (15\%) and reduction 17 (85\%); fusion levels: L3-S1: 1 (5\%), L3-lliac: 1 (5\%), L4-S1: 1 (5\%), L4-lliac: 6 (30\%) and L5-S1: 11 (55\%). Comparing the pre- and postoperative parameters, a significant improvement $(p<0.05)$ was seen in the VAS, T1 slope, T1 pelvic angle (TPA), slip angle, Dubousset's lumbosacral angle and slip \%. Evaluating the correlation between the variation in sagittal parameters and the improvement in VAS scale, it was found that the TPA showed a strong correlation ( $r=0.709, \mathrm{p}=0.032)$. Conclusions: the present study found a strong correlation between the improvement/ reduction in TPA values and the reduction in pain intensity in the VAS. Level of evidence IV; Case Series.
\end{abstract}

Keywords: Spondylolisthesis; Spinal Fusion; Quality of Life.

\section{RESUMO}

Objetivo: Avaliar a correlação entre as variáveis do alinhamento sagital global e a melhora da dor após a cirurgia de espondilolistese de alto grau (EAG). Métodos: Uma amostra com 20 pacientes com espondilolistese de alto grau L5-S1, submetidos à artrodese com instrumentação, de 01/2004 a 12/2016. Os dados demográficos dos pacientes, tipos de cirurgias, complicações, parâmetros do alinhamento sagital e escore da Escala Visual Análoga (EVA) (variando de 0 a 4) foram registrados antes da cirurgia e no último acompanhamento. Os dados foram processados no SPSS 22.0. O nível de confiança foi 0,05. Resultados: A maioria da amostra foi composta por mulheres, 17 (85\%);

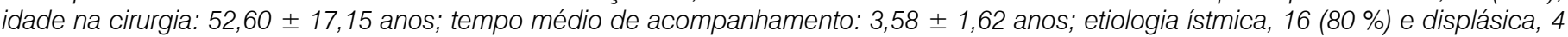
(20\%); Grau Meyerding 3: 12 (60\%), Grau 4: 3 (15\%) e Grau 5: 5 (25\%); SDSG tipo 4: 6 (30\%), tipo 5a: 3 (15\%), 5b: 3 (15\%), tipo 6: 7 (35\%) e não classificado 1 (5\%); cirurgia: fusão no local 3 (15\%) e redução 17 (85\%); níveis de fusão: L3-S1, 1 (5\%), L3-llíaco: 1 (5\%), L4-S1: 1 (5\%), L4-Ilíaco: 6 (30\%) e L5-S1: 11 (55\%). Comparando-se os parâmetros pré- e pós-operatório, observou-se uma melhora significativa (p $<0,05)$ na EVA, declive de T1, ângulo T1 pélvico (ATP), ângulo de deslizamento, ângulo lombossacral de Dubousset e \% de deslizamento. Avaliando-se a correlação entre a variação dos parâmetros sagitais com a melhora na escala EVA, verificou-se que o ATP apresentou forte correlação $(r=0,709, p=0,032)$. Conclusões: O presente estudo encontrou uma forte correlação entre a melhora/redução nos valores de ATP e na redução na intensidade da dor na EVA. Nível de evidência IV; Série de casos.

Descritores: Espondilolistese; Fusão Vertebral; Qualidade de Vida.

\section{RESUMEN}

Objetivo: Evaluar la correlación entre las variables de la alineación sagital global y la mejora del dolor después de la cirugía para espondilolistesis de alto grado (EAG). Métodos: Una muestra con 20 pacientes con espondilolistesis de alto grado L5-S1, sometidos a la artrodesis con instrumentación, de 01/2004 a 12/2016. Los datos demográficos de los pacientes, tipos de cirugías, complicaciones, parámetros de la alineación sagital y puntuación de la Escala Visual Análoga (EVA) (variando de 0 a 4) fueron registrados antes de la cirugía y en el último acompañamiento. Los datos fueron procesados en SPSS 22.0. El nivel de confianza fue de 0,05. Resultados: La mayoría de la muestra fue compuesta por mujeres, 17 (85\%); edad en la cirugía: 52,60 \pm 17,15 años; tiempo promedio de acompañamiento: 3,58 \pm 1,62 años; etiología ístmica, 16 (80\%) y displásica, 4 (20\%); Grado Meyerding 3: 12 (60\%), Grado 4: 3 (15\%) y Grado 5: 5 (25\%); SDSG tipo 4: 6 (30\%), tipo 5a: 3 (15\%), 5b: 3 (15\%), tipo 6: 7 (35\%) y no clasificado 1 (5\%); cirugía: fusión en el local 3 (15\%) y reducción 17 (85\%); 
niveles de fusión: L3-S1, 1 (5\%), L3-llíaco: 1 (5\%), L4-S1: 1 (5\%), L4-llíaco: 6 (30\%) y L5-S1: 11 (55\%). Comparándose los parámetros pre y postoperatorio, se observó una mejora significativa $(p<0,05)$ en la EVA, pendiente de T1, ángulo T1 pélvico (ATP), ángulo de deslizamiento, ángulo lumbosacro de Dubousset y \% de deslizamiento. Evaluándose la correlación entre la variación de los parámetros sagitales con la mejora en la escala EVA, se verificó que el ATP presentó fuerte correlación ( $r=0,709, p=0,032)$. Conclusiones: El presente estudio encontró una fuerte correlación entre la mejora/reducción en los valores de ATP y en la reducción en la intensidad del dolor en la EVA. Nivel de evidencia IV; Serie de Casos.

Descriptores: Espondilolistesis; Fusión Vertebral; Calidad de Vida.

\section{INTRODUCTION}

Spondylolisthesis is an anterior or posterior displacement between adjacent vertebrae. Slips of more than $50 \%$ are defined as high grade spondylolisthesis, and are classed as more severe, though they affect only $1 \%$ of patients. ${ }^{1}$

In high grade cases, there is generally kyphosis of the L5 vertebra in relation to the $\mathrm{S} 1$. In these patients, compensation first occurs through an increase in lumbar lordosis (LL), followed by the increase in pelvic retroversion that leads to an increase in the pelvic tilt (PT), reducing the sacral slope. When these mechanisms of physiological compensation are ineffective in neutralizing the L5-S1 kyphosis, the patient then develops a positive global sagittal imbalance, which is posteriorly compensated by flexing the knees and hip, leading to Phalen-Dickson gait.?

There is increasing awareness in literature of the close correlation between the spinopelvic sagittal alignment and quality of life measures related to health $(\mathrm{QLRH})$, which include incapacitation and pain in patients with high grade listhesis. ${ }^{3}$

This main aim of this study is to evaluate the correlation between changes in global sagittal alignment and improvement in pain levels after HGS surgery.

\section{METHODS}

This is a study of a series of cases comprised of a sample of 20 patients who had undergone surgical treatment for high grade lumbosacral spondylolisthesis at a national reference hospital for spinal pathologies, during the period January 2004 (date of the first computerized record of this pathology in the hospital database) to December 2016 (last patient with a minimum period of 2 years since surgery).

The criteria for inclusion in the research were as follows: subjects of both sex, who had undergone surgery for high grade spondylolisthesis (Meyerding grade $>3$ ) between L1 and S1, through the spinal service of the aforementioned institution; availability of only one lateral standing $x$-ray showing the spine, pelvis, and proximal femurs before the surgery and at the last follow-up; availability of visual analogue scale (VAS) (varying from 0 to 4 , with 0 being no pain, and 4 excruciating pain) before the surgery and at the last follow-up; no previous surgery involving the spine, pelvis or lower limbs; no pathology of the lower limbs, such as hip dysplasia; no ankylosing disease, such as ankylosing spondylitis, diffuse idiopathic skeletal hyperostosis or Forestier syndrome, and a minimum follow-up of 2 years.

Information about the patients demographic data, surgical indications, surgical details, and complications were recorded, based on the patients' records. Retrospective and current measurements of the sagittal alignment of the radiological parameters were conducted in all patients. The panoramic $x$-rays in AP and Profile of the spinal cord in orthostasis were also evaluated, according to the service protocol, being reviewed independently.

The pain evaluation was conducted by recording, in the patients' records, the visual analogue scale (VAS) in which the patients classified the intensity of their pain according to the mimicry represented in drawings shown of a face, with no pain (grade 0), represented by happy face; mild pain (grade 1) by a face expressing affliction; moderate pain (grade 2), by a sad face; strong pain (grade 3) by a face with a miserable expression; and finally, excruciating pain (grade 4) represented by a crying face. ${ }^{4,5}$

The other variables were comprised of: spondylolisthesis' etiology; Meyerding grading; SDSG classification; cervical lordosis from C2 to C7; cervical SVA (cSVA); T1 slope; TPA (T1 pelvic angle); thoracic kyphosis from T5 to T12; lumbar lordosis from L1 to L5, and from L1 to S1; slip angle; Dubousset's lumbosacral kyphosis angle; slip percentage; pelvic incidence (PI); pelvic tilt (PT); sacral slope (SS); L5 pelvic incidence (L5I); L5 pelvic tilt (L5T); L5 slope; proximal femoral angle (PFA); SVA and mismatch (MM).

The data were processed using the program SPSS 2.0 for Windows, Inc., Chicago, IL, USA, license number 10101131007. The study population was characterized through descriptive and comparative analysis. Averages and standard deviations for the pre- and postsurgical parameters were calculated through the student's t-test for paired data. The correlation between the VAS scale and Pearson's $r$ correlation coefficient parameters was analyzed. For the inferential analysis, those with $p<0.05$ were considered statistically significant.

According to National Health Council resolutions 466/2012 and 580/2018, the present study was approved by the institution's Research Ethics Committee, with statement 3.241.077. Since this is a retrospective study, the use of a free consent legal term was not necessary.

\section{RESULTS}

Descriptive analysis was used to summarize the patients' characteristics and the surgical procedure. The majority of the sample were women, 17 (85\%); age at the time of the surgery: $50.62 \pm$ 17.15 years; average follow-up: $3.85 \pm 1.62$ years; isthmic etiology in $16(80 \%)$ and dysplastic etiology in $4(20 \%)$; Meyerding grade 3 : $12(60 \%)$, grade $4: 3(15 \%)$, and grade 5: $5(25 \%)$; type 4 SDSG: 6 (30\%), type 5a: 3 (15\%), type 5b: 3 (15\%), type 6: 7 (35\%), and notclassified: 1 (5\%); types of surgery: in situ fusion: $3(15 \%)$, reduction: 17 (85\%); surgical technique: PLIF: 9 (45\%), ruf + PLIF: 8 (40\%), Gaines: 2 (10\%), and Bohlman: 1 (5\%); fusion levels: L3-S1: 1 (5\%), L3-lliac: 1 (5\%), L4-S1: 1 (5\%), L4-lliac: 6 (30\%) and L5-S1: 11 (55\%).

Comparing the pre- and postsurgical parameters, a significant improvement $(p<0.05)$ was noted in the following variables: visual analogue scale (VAS); T1 slope; T1 pelvic angle (TPA); slip angle; Dubousset's lumbosacral angle; and slip \%. (Table 1)

Evaluating the correlation between variation in sagittal parameters and improvement on the VAS scale, it was noted that the TPA presented a strong correlation $(r=0.709, p=0.032)$. (Table 2)

The following complications were noted: wound infection in 3 (37.5\%); surgical screw release, 1 (12.5\%); pseudarthrosis, 2 (25\%); implant-related pain, 1 (12.5\%); and dural lesion, 1 (12.5\%).

\section{DISCUSSION}

Deformity in the area of a high grade slip may cause some compensatory changes in the regional pelvic anatomy, which are then propagated through the spinal cord, creating a global deformity. These compensatory mechanisms to maintain sagittal alignment require significant energy expenditure, which may cause pain and incapacitation in these patients. ${ }^{3,6}$

An improvement of two points in the visual numerical analogue scale is considered a good clinical result in terms of pain improvement. ${ }^{4}$ In our study, the visual analogue scale was used, with grades ranging from zero to four. There was a significant reduction of almost two points on the pain scale in the postsurgical evaluation compared with the presurgical period, in the patients who took part in this research. 
Table 1. Comparison between preoperative and final postoperative parameters.

\begin{tabular}{|c|c|c|c|}
\hline Parameters & Preoperative & Postoperative & $\mathbf{P}$ \\
\hline VAS & $2.75 \pm 1.342$ & $1.06 \pm 0.998$ & $<0.001$ \\
\hline Cervical lordosis $(\mathrm{C} 2-\mathrm{C} 7)(\circ)$ & $10.60 \pm 6.63$ & $14.93 \pm 11.79$ & 0.28 \\
\hline cSVA $(\mathrm{cm})$ & $4.53 \pm 5.19$ & $2.22 \pm 1.12$ & 0.13 \\
\hline Slope T1 (०) & $16.54 \pm 10.71$ & $23.53 \pm 10.21$ & 0.02 \\
\hline TPA (०) & $19.46 \pm 11.39$ & $9.08 \pm 13.13$ & 0.20 \\
\hline Thoracic kyphosis (T5-T12) (०) & $24.44 \pm 19.09$ & $26.88 \pm 15.38$ & 0.52 \\
\hline Lumbar lordosis (L1-S1) (०) & $-56.63 \pm 16.22$ & $-50.89 \pm 27.38$ & 0.36 \\
\hline Lumbar lordosis (L1-L5) (॰) & $-54.60 \pm 11.64$ & $-52.70 \pm 11.14$ & 0.53 \\
\hline Slip Angle (०) & $14.11 \pm 23.95$ & $2.30 \pm 16.04$ & 0.01 \\
\hline $\begin{array}{c}\text { Dubousset's lumbosacral } \\
\text { angle }\left({ }^{\circ}\right)\end{array}$ & $84.70 \pm 29.34$ & $102.9 \pm 24.95$ & 0.001 \\
\hline Slip \% & $71.20 \pm 19.95$ & $44.90 \pm 18.11$ & $<0.001$ \\
\hline $\mathrm{PI}\left({ }^{\circ}\right)$ & $66.05 \pm 11.28$ & - & - \\
\hline PT (०) & $24.20 \pm 11.39$ & $22.30 \pm 11.90$ & 0.34 \\
\hline $\begin{array}{l}\text { SS (०) } \\
\text { L5I (०) }\end{array}$ & $\begin{array}{l}41.95 \pm 11.61 \\
48.25 \pm 25.21\end{array}$ & $\begin{array}{l}43.70 \pm 9.03 \\
40.80 \pm 16.26\end{array}$ & $\begin{array}{l}0.39 \\
0.27\end{array}$ \\
\hline L5T (०) & $17.45 \pm 12.47$ & $12.30 \pm 9.69$ & 0.10 \\
\hline L5S (०) & $40.56 \pm 17.77$ & $30.55 \pm 11.91$ & 0.03 \\
\hline PFA (०) & $8.63 \pm 5.61$ & $7.07 \pm 2.57$ & 0.24 \\
\hline SVA $(\mathrm{cm})$ & $4.82 \pm 5.01$ & $5.66 \pm 3.53$ & 0.60 \\
\hline Mismatch (०) & $7.80 \pm 15.74$ & $10.25 \pm 13.74$ & 0.45 \\
\hline
\end{tabular}

$\mathrm{p}$ by the Student's t-test.

Table 2. Correlation between sagittal parameters and variation in VAS scale (post- and preoperative)

\begin{tabular}{|c|c|c|}
\hline Parameters & $\mathbf{R}$ & $\mathbf{P}$ \\
\hline$\triangle$ VAS vs. $\triangle$ Cervical Lordosis & 0.326 & 0.32 \\
\hline$\triangle$ VAS vs. $\triangle \mathrm{cSVA}$ & 0.198 & 0.55 \\
\hline$\triangle$ VAS vs. $\triangle$ SLOPE T1 & 0.414 & 0.20 \\
\hline$\triangle$ VAS vs. $\triangle T P A$ & 0.755 & 0.02 \\
\hline$\Delta$ VAS vs. $\Delta$ Thoracic Kyphosis (T5-T12) & 0.183 & 0.56 \\
\hline$\triangle$ VAS vs. $\triangle$ Lumbar Lordosis (L1-S1) & 0. 160 & 0.56 \\
\hline$\triangle$ VAS vs. $\Delta$ Lumbar Lordosis (L1-L5) & 0.256 & 0.33 \\
\hline$\triangle$ VAS vs. $\triangle$ Slip Angle & -0.039 & 0.88 \\
\hline$\triangle$ VAS vs. $\triangle$ Dubousset's lumbosacral angle & -0.334 & 0.20 \\
\hline$\triangle$ VAS vs. $\triangle$ slip $\%$ & 0.135 & 0.61 \\
\hline$\triangle$ VAS vs. $\triangle \mathrm{PT}$ & -0.123 & 0.65 \\
\hline$\triangle$ VAS vs. $\triangle S S$ & 0.130 & 0.63 \\
\hline$\triangle$ VAS vs. $\Delta$ L5I & 0.118 & 0.66 \\
\hline$\triangle$ VAS vs. $\triangle \mathrm{L} 5 \mathrm{~T}$ & -0.276 & 0.30 \\
\hline$\triangle$ VAS vs. $\triangle \mathrm{L} 5 \mathrm{~S}$ & 0.054 & 0.84 \\
\hline$\triangle$ VAS vs. $\triangle \mathrm{AFP}$ & -0.329 & 0.32 \\
\hline$\triangle$ VAS vs. $\triangle S V A$ & -0.033 & 0.92 \\
\hline
\end{tabular}

$r$ (Pearson's Correlation).
Tanguay et al. ${ }^{7}$ report, in their study, that an increase in lumbosacral kyphosis is closely correlated with a reduction in the patients' quality of life, when they have spondylolisthesis L5-S1, especially when there is a high grade slip, regardless of the percentage. It was noted that Dubousset's lumbosacral kyphosis angles greater than $80^{\circ}$ and slip angles less than $30^{\circ}$ were correlated with better quality of life scores.

According to some authors ${ }^{8}$ there is an inverse correlation between the Dubousset's lumbosacral kyphosis angle and the grade of slip. Patients who present low values on the lumbosacral kyphosis angle have a higher grade of slip, and vice-versa.

Our study pointed to a significant reduction in the slip angle, with an average final value of $2.3^{\circ}$, and an increase in the Dubousset's lumbosacral kyphosis angle, with an average postsurgical value greater than $100^{\circ}$. All this was associated with a significant reduction in the grade and percentage of slip.

Evaluating the correlation between improvement in pain levels and the sagittal alignment parameters, it was noted that the reduction/improvement in T1 pelvic slip angle (TPA) presented strong correlation with improvement of pain levels in the patients who took part in this study.

An International Spine Study Group9 study introduced the concept of TPA, a new angular measure of the global sagittal alignment, which takes into consideration not only the sagittal vertical axis but also the pelvic inclination, simultaneously, resulting in a sum of the T1 inclination and the pelvic inclination. Since it is an angular measure that is not reduced by many postural compensatory mechanisms, it presents advantages over established techniques used to measure sagittal deformities.

According to these authors ${ }^{9}$ the T1 pelvic angle can be used as perioperative tool for evaluating how adequate is the global sagittal correction, with a target $<14^{\circ}$ being related to a lower score of incapacitation. In our study, the average postsurgical values of TPA was around $9^{\circ}$.

\section{CONCLUSION}

The present study noted the improvement of values in the variables of sagittal alignment, such as slip angle, and Dubousset's lumbosacral kyphosis angle. This points to the correction of the lumbosacral deformity with the intent of restoring the global sagittal alignment in these patients. Furthermore, a strong correlation was found between the improvement/reduction of the TPA values and the reduction of the pain levels in the visual analogue scale.

The inherent limitations of a retroactive study, such as the non-random sampling of patients, as well as the presence of confounders, must also be considered. The authors believe that more prospective studies are needed, with random sampling, to evaluate which parameters are best directly related to the improvement of pain levels, and incapacitation scores in patients who have undergone surgery for high grade spondylolisthesis.

\section{ACKNOWLEDGEMENT}

The authors thank the employees of the National Institute of Traumatology and Orthopedics: Marcela Alves Muniz, Francimar Abrahão dos Santos, Dainara dos Santos Machado, Fernanda Costa de Souza and Urbano Pedrito Estrela da Silva Filho for the technical support provided during the preparation of the survey.

All authors declare no potential conflict of interest related to this article.

CONTRIBUTION OF THE AUTHORS: Each author made significant individual contributions to this manuscript. JAAO: writing, statistical analysis, intellectual concept and preparation of the entire research project; VTGS: writing, review and intellectual concept; LEPCAA: writing, review and intellectual concept; RSPM: writing, review and performing the surgeries; GRL: writing, review and performing the surgeries; APM: writing, review and performing the surgeries; PCA: statistical analysis, writing and review; LECTS: writing, review and performing the surgeries. 


\section{REFERENCES}

1. Passias PG, Poorman CE, Yang S, Boniello AJ, Jalai CM, Worley N, et al. Surgical Treatment Strategies for High-Grade Spondylolisthesis: A Systematic Review. Int J Spine Surg. 2015;9(50):1-21.

2. Hoel RJ, Brenner RM, Polly Jr. The Challenge of Creating Lordosis in High-Grade Dysplastic Spondylolisthesis. Neurosurg Clin N Am. 2018(29):375-87.

3. Gussous Y, Theologis AA, Demb JB, Tangtiphaiboontana J, Berven S. Correlation Between Lumbopelvic and Sagittal Parameters and Health-Related Quality of Life in Adults With Lumbosacral Spondylolisthesis. Global Spine Journal. 2018;8(1):17-24.

4. Falavigna A, Teles AR, Braga GL, Barazzetti DO, Lazzaretti L, Tregnago AC Instrumentos de Avaliação Clínica e Funcional em Cirurgia da Coluna Vertebral. Coluna/Columna. 2011:10(1):62-7.

5. Wong D, Hockenberry-Eaton M, Wilson D, Winkelstein M, Schwartz P. Wong's essentials of pediatric nursing. St.Louis, Mi: Elsevier; 2001.
6. Gandhoke GS, Kasliwal MK, Smith JS, Nieto J, Ibrahimi D, Park P, et al. A MultiCenter Evaluation of Clinical and Radiographic Outcomes Following High Grade Spondylolisthesis Reduction and Fusion. Clin Spine Surg. 2017;30(4):E363-E9.

7. Tanguay F, Labelle H, Wang Z, Joncas J, Guise JA, Mac-Thiong JM. Clinical Signifi cance of Lumbosacral Kyphosis in Adolescent Spondylolisthesis. Spine (Phila Pa 1976). 2012;37(4):304-8.

8. Jabłońska-Sudoł K, Maciejczak A. Relationship between the spino-pelvic parameters and the slip grade in isthmic spondylolisthesis. Neurol Neurochir Pol. 2015;49(38):381-388

9. Protopsaltis T, Schwab F, Bronsard N, Smith JS, Klineberg E, Mundis G, et al. The T1 Pelvic Angle, a Novel Radiographic Measure of Global Sagittal Deformity, Accounts for Both Spinal Inclination and Pelvic Tilt and Correlates with Health-Related Quality of Life. J Bone Joint Surg Am. 2014;96(19):1631-40. 